\title{
Exploring e-Commerce Readiness in China: The Case of the Grocery Industry
}

\author{
Sherah Kurnia \\ Department of Information Systems \\ The University of Melbourne, Australia \\ E-mail: sherahk@unimelb.edu.au
}

\begin{abstract}
Electronic Commerce which enables business transactions to be conducted electronically has demonstrated significant operational and strategic benefits. Developed countries have actively adopted eCommerce and have made it an integral part of business activities. Despite its ability to bridge economic and digital gap between developing and developed countries, developing countries are still slow in e-Commerce adoption. Currently, there is still a lack of e-Commerce readiness research in developing countries to fully assess the relevance of e-Commerce in these unique environments. This study aims to shed light into the eCommerce readiness in China, by assessing technological, organizational and environmental contexts of the grocery industry. The uniqueness of China in various aspects including cultural, economic and political, poses different challenges and requires different strategies to encourage widespread adoption of e-Commerce.
\end{abstract}

\section{Introduction}

Electronic Commerce (e-Commerce) is concerned with conducting business transactions electronically using information and communication technologies [14]. It is not only limited to buying and selling over the Internet, but also the transferring or exchanging of products/services and/or information via computer networks, including the Internet, Extranet and Intranet. Activities such as servicing customer online, collaborating with business partners and exchanging business documents within an organization over the Internet or other private networks are all regarded as a part of e-Commerce. Because of its broad coverage, ecommerce is often referred to as e-business[11].

Electronic Commerce offers many potential benefits particularly in productivity gains and transaction cost reductions. The rapid dissemination of information, the digitization of record keeping, and the networking capability of the Internet has improved flexibility and responsiveness, encouraged new and more efficient intermediaries, increased the use of outsourcing, expanded market access, reduced time to market by linking orders to production, and improved internal coordination [14].
Because of its potential, e-Commerce has been rapidly adopted by many countries in this globalization era [3]. However, the e-Commerce adoption is unilaterally concentrated in developed countries. According to United Nations Conference on Trade and Development (UNCTAD), 95\% of e-Commerce takes place in developed countries, with Africa and Latin America combined accounting for less than $1 \%$ of the total [34]. In 2004, only 3\% of Africans had access to the Internet, in sharp contrast to $67 \%$ of North Americans. These figures demystify the divide which exists between developed and developing nations.

E-Commerce has the potential to bridge the digital divide because its benefits have positive effects on nations' development through improving access to information, knowledge and expertise, enhancing competitiveness through access to wider markets, increasing labor productivity, to name a few, which will, in turn, lead to reduction in poverty [29, 30]. However, there is still skepticism about the positive expectations of e-Commerce for developing countries [26]. Although referred to as a catalyst to bridge the economic disparities and digital gap between developed and developing countries, e-Commerce, in reality, has widened the gap and further marginalized the developing countries due to their inability to implement and deploy e-Commerce technologies judiciously [3]. Such disparity could be explained by the differences in e-Commerce readiness between developed and developing nations because of different country and business conditions.

Despite the importance of e-Commerce readiness studies in developing countries to further promote adoption, there are still very limited studies in this area. Therefore, this study is designed to address the gap in the literature by assessing the e-Commerce readiness in People's Republic of China, or simply China, as an example of a developing country. For this purpose, Tornatzky and Fleischer (1990) technology-organizationenvironment framework is used as a theoretical framework. This study aims to understand China's current and future e-Commerce adoption, by examining its current information technology (IT) adoption, national infrastructure and organizational context. A multiple case study involving various organizations within the Chinese grocery industry is used as the research method. The grocery industry is chosen because the industry has been pioneering the technology adoption in various countries because of the characteristics of the 
industry that involves high transaction volumes and low profit margins.

The findings indicate that, in general, the level eCommerce readiness in China, particularly within the grocery industry, is still low. The study further suggests that because of the nature of the competition, the Chinese consumers' unique behavior, as well as the social, political and economic conditions of the country, eCommerce has the potential to streamline the business processes of the organizations within the industry to achieve improvement in efficiency, effectiveness and profitability. However, because of the uniqueness of China and the grocery industry, different strategies are required to encourage further adoption of e-Commerce.

The next section presents a literature review on the Chinese grocery industry, outlining the historical development, industry characteristics and major players. Then the potential of e-Commerce for the industry and an overview of information technologies currently in use are presented. A brief discussion of the theoretical framework and the research method are then outlined, followed by a discussion of the findings. Finally, the paper concludes with the implications of the study and suggestions for effective adoption of e-Commerce within the Chinese grocery industry.

\section{Chinese Grocery Industry}

Because of the changes in the political, social and economic environments, the Chinese grocery industry has evolved over time, developing numerous retail formats from wet markets, retail-cooperatives to supermarkets. Table 1 summarizes the evolution of Chinese grocery industry.

Before the Chinese Communist Party (CCP) became the ruling party, China's retail sector was dominated by small shops and wet markets. These store formats were later taken over by the retail-cooperatives and stateowned enterprises (SOE) when the CCP became the ruling party. The distribution of grocery items remained under the strict state control until the economic liberalization which happened in the early 1980s. The economic liberalization allowed private ownership of retail and wholesale operations.

The supermarket format was first introduced during this period, but its growth was hampered by a lack of appropriate suppliers and the high price charged [19]. However, the supermarket experienced an exponential growth during the 1990s to the 2000s. The arrival of western culture and the growing consumer purchasing power have increased supermarkets' popularity among the Chinese consumers. By 2004, the supermarket has grown into a US\$55 billion industry, consisting of approximately 53,000 units and occupying a share of $30 \%$ of urban food market $[13,19]$.

\subsection{Chinese Consumer Behavior}

While the grocery industry is being shaped by cultural, political and economical forces over time, the Chinese consumers have also developed a set of unique behavior which has fundamental impacts on the characteristics of China's supermarkets. Being raised in a collective society with the influence of the Confucius philosophy, the Chinese consumers are extremely price conscious and tend to be very informed and disloyal shoppers. They are willing to search extensively for a better deal and consider it to be a leisure-activity[1]. Meanwhile, the vast geographical coverage and sophisticated local cultures also caused Chinese consumers to have significantly different product preferences and value systems, varying from city to city [1].

Table 1: The Evolution of Chinese Grocery Industry

\begin{tabular}{|c|c|c|}
\hline Year & Format & Description \\
\hline $\begin{array}{l}\text { Before } \\
1949\end{array}$ & $\begin{array}{l}\text { Wet markets, } \\
\text { street markets, } \\
\text { small shops }\end{array}$ & $\begin{array}{l}\text { These were private retail sectors. } \\
\text { Distribution system was virtually } \\
\text { nonexistent. Grocery needs were } \\
\text { fulfilled locally. }\end{array}$ \\
\hline $\begin{array}{l}1953- \\
1958\end{array}$ & $\begin{array}{l}\text { Retail co- } \\
\text { operatives, } \\
\text { State-owned } \\
\text { enterprises (SOE) }\end{array}$ & $\begin{array}{l}\text { Chine Communist Party (CCP) } \\
\text { dictated a state controlled economy. } \\
\text { Private retailers were either formed } \\
\text { into retail co-operatives or bought } \\
\text { out to establish SOEs to sell basic } \\
\text { food at low prices. }\end{array}$ \\
\hline $\begin{array}{l}1959- \\
1980\end{array}$ & $\begin{array}{l}\text { State-owned } \\
\text { enterprises (SOE) }\end{array}$ & $\begin{array}{l}\text { CCP expanded the control on } \\
\text { China's economic activities and } \\
\text { extended SOE retail sector to urban } \\
\text { areas }\end{array}$ \\
\hline $\begin{array}{l}1981- \\
1990\end{array}$ & $\begin{array}{l}\text { Wet markets, } \\
\text { provisional } \\
\text { shops, } \\
\text { staple food } \\
\text { stores, } \\
\text { supermarkets } \\
\text { (marginal-player) }\end{array}$ & $\begin{array}{l}\text { Economic liberalization began. Wet } \\
\text { markets and small shops which sell } \\
\text { grocery items in the urban areas } \\
\text { started to flourish again. In March } \\
1981 \text {, the first supermarket in China } \\
\text { was established in Guangzhou } \\
\text { catering for foreign tourists. }\end{array}$ \\
\hline $1990 \mathrm{~s}$ & $\begin{array}{l}\text { Supermarkets, } \\
\text { wet markets } \\
\text { street markets, } \\
\text { staple food stores }\end{array}$ & $\begin{array}{l}\text { Supermarket format experienced an } \\
\text { exponential growth in the large } \\
\text { cities and special economic zones } \\
\text { due to their consumers high } \\
\text { purchasing power. }\end{array}$ \\
\hline $\begin{array}{l}\text { Late } \\
1990 \mathrm{~s}- \\
\text { now }\end{array}$ & $\begin{array}{l}\text { Supermarkets, } \\
\text { wet markets, } \\
\text { street markets }\end{array}$ & $\begin{array}{l}\text { Supermarket started to move into } \\
\text { other cities in the eastern region and } \\
\text { extended into large cities in the } \\
\text { central region. }\end{array}$ \\
\hline
\end{tabular}

In order to address such consumer behavior, China's supermarkets are under constant pressure to offer low prices and a wide range of products to facilitate Chinese consumers' product search and comparison habit. Commonly used sale generation strategies such as lossleaders strategy, are usually unable to generate expected results due to Chinese consumers' preference for small frequent grocery shopping $[9,10,21]$. In addition, differences in local product preferences made it 
impossible to centralize inventory management among chain stores and, as a result, local sourcing and directstore delivery distribution strategy are common among China's supermarket chains. These Chinese consumer characteristics and behavior pose unique challenges to the supermarkets and consequently require different strategies compared to supermarkets in developed countries, which are summarized in Table 2. These unique market characteristics have caused unexpected problems among the first wave of foreign investors. After rushing into the Chinese market, foreign chains frequently fail to replicate their successes in the home countries $[9,10,21]$.

Table 2: Consumer behavior and its impact on China's supermarkets

\begin{tabular}{|l|l|l|l|}
\hline $\begin{array}{l}\text { Con- } \\
\text { sumer } \\
\text { Characte } \\
\text { ristics }\end{array}$ & $\begin{array}{l}\text { Consumer } \\
\text { Behavior }\end{array}$ & $\begin{array}{l}\text { Supermarket } \\
\text { Challenges }\end{array}$ & $\begin{array}{l}\text { Supermarket } \\
\text { Strategy }\end{array}$ \\
\hline $\begin{array}{l}\text { Price } \\
\text { con- } \\
\text { scious }\end{array}$ & $\begin{array}{l}\text { Extensive } \\
\text { product search }\end{array}$ & $\begin{array}{l}\text { Under constant } \\
\text { pressure to offer } \\
\text { low price }\end{array}$ & $\begin{array}{l}\text { Frequent sales } \\
\text { and price wars } \\
\text { among } \\
\text { supermarkets }\end{array}$ \\
\hline Disloyal & $\begin{array}{l}\text { Shop from a } \\
\text { number of } \\
\text { supermarkets, } \\
\text { based on price } \\
\text { and product } \\
\text { offerings. }\end{array}$ & $\begin{array}{l}\text { Hard to maintain } \\
\text { a stable customer } \\
\text { base, under } \\
\text { constant pressure } \\
\text { to attract and } \\
\text { retain customers. }\end{array}$ & $\begin{array}{l}\text { Offer huge } \\
\text { range of } \\
\text { products from } \\
\text { white goods to } \\
\text { cosmetics. }\end{array}$ \\
\hline $\begin{array}{l}\text { View } \\
\text { grocery } \\
\text { shopping } \\
\text { as leisure } \\
\text { activity }\end{array}$ & $\begin{array}{l}\text { Frequent, } \\
\text { small shopping } \\
\text { trips }\end{array}$ & $\begin{array}{l}\text { Sales generating } \\
\text { strategy fail to } \\
\text { have spill-over } \\
\text { effect on } \\
\text { normally priced } \\
\text { products }\end{array}$ & $\begin{array}{l}\text { Extensive sales } \\
\text { range, heavy } \\
\text { advertising and } \\
\text { frequent } \\
\text { promotional } \\
\text { activities }\end{array}$ \\
\hline $\begin{array}{l}\text { Local } \\
\text { pre- } \\
\text { ferences }\end{array}$ & $\begin{array}{l}\text { Distinct } \\
\text { product } \\
\text { preferences in } \\
\text { different } \\
\text { regions. }\end{array}$ & $\begin{array}{l}\text { Different } \\
\text { inventory } \\
\text { requirements in } \\
\text { different regions, } \\
\text { which makes it } \\
\text { difficult to } \\
\text { manage inventory } \\
\text { centrally. }\end{array}$ & $\begin{array}{l}\text { Inventory is } \\
\text { managed on a } \\
\text { store basis. } \\
\text { Direct-store } \\
\text { delivery and } \\
\text { local sourcing } \\
\text { are common } \\
\text { practices. }\end{array}$ \\
\hline
\end{tabular}

Furthermore, Chinese consumers' obsession over price has made the competition within the supermarket sector especially furious. New entrants can easily attract a large number of customers from established chains by offering lower prices and it is a constant struggle to retain market share among the existing players. Continuous price and promotion wars are raging among the major chains, thinning their profits. The intrusion of foreign supermarket chains armed with modern management concepts and technologies further increased the intensity of the competition. To stay competitive, China has seen frequent consolidations of Chinese chains to form retail giants such as the Bailian group. Consequently, as Mousteraski (2001) estimates, an average of 350,000 small shops has to go out of business [25].

\subsection{Major players and their operations}

In the last few decades, the Chinese grocery industry has seen a significant shift of power in favor of the retailers [20]. The demolition of state controlled grocery distribution system has catalyzed the development in the retail sector with powerful players such as Lianhua, Suguo and Carrefour dominating the market, with enormous buying power.

Meanwhile, the former state-owned distribution system was left behind, with no significant growth over the past years. Coupled with the Chinese economy's transformation from sellers' market to buyers' market, retailers gained dominant position in the marketing channel $[3,20]$. There are currently no major players in the distribution sector that can compete with the power of retailer giants such as Carrefour or Bailian, with the large majority of the sector remains extremely fragmented. These distributors remain small in size and usually specialize in a specific area / product category [3]. As a result, products that go through the conventional distribution channels typically have to be handled by various parties before reaching their destination.

The under development of the distribution sectors has imposed significant difficulty in inventory management for the supermarkets. Smaller supermarkets usually procure supplies directly from the wholesalers with limited direct-supply relationships for certain products [13]. Large chains, on the other hand, may use pick-andpack approach (Suguo), direct-store delivery (Carrefour) or third-party logistic (Wal-Mart) system depending on their focus and size. Limited e-Commerce technologies such as B2B portals are used among these major chains to enable information exchange between the supply chain partners while the smaller chains still deploy manual procurement procedures.

\section{The Potential of E-Commerce for the Chinese Grocery Industry}

Based on the characteristics of the Chinese grocery industry and its consumers, e-Commerce has great potential to offer. It is able to enhance the organizational performance in several ways. Firstly, in terms of administration and daily operations, grocery industry's labor intensive nature and the enormous volume of transactions made administration and transaction processing extremely demanding. E-Commerce's ability to automate day-to-day document exchange and communications within and between organizations can significantly enhance their operational efficiency as well as reduce administration costs. Even the simple internal E-mail system will greatly enhance the efficiency of information dissemination within the firm and reduce 
associated paperwork and telecommunication costs [2, 17]. Operational efficiency will enable the industry to offer low costs to the consumers.

Secondly, inventory management and supply chain coordination is crucial to the performance of the firms because the retailers are expected to offer a wide range of products to suit the Chinese consumers' behavior in product search and comparison. The ability to manage inventory efficiently and effectively can therefore generate significant advantage for the firms in the industry where low-prices is merely a point of competitive parity. E-Commerce, therefore, has many to offer to the industry in streamlining the product and information flow within the supply chains so that inventory level can be kept minimum while product range can be increased. Advanced supply chain management practices such as Vendor Managed Inventory (VMI) and cross-docking, which are enabled by various e-Commerce technologies, will not only enhance product replenishment efficiencies but also reduce the associated transaction costs $[17,31]$.

Lastly, Chinese consumers' ever changing preferences and demands have made it especially important for the firms to respond quickly to the changing market needs. By facilitating real-time market feedback through websites and other mechanisms, eCommerce is able to provide better information to assist the strategic decision making process within firms. It consequently enhances firms' responsiveness to the market and environment.

\section{Current Use of Information Technologies}

China is a late adopter of information technologies (IT) as most of the IT infrastructure was not deployed by the majority of Chinese firms until the late 1990s. Firms in the grocery industry have been introducing standalone computers to their stores and offices in the 1990s but the build-up of hardware and software for Enterprise Resource Planning (ERP) and other decision supporting functions only began two to three years ago [28]. Since the liberalization of Chinese economy, recently developed information technologies such as the Internet were quickly adopted by the grocery industry. Enterprise applications and other applications such as Electronic Data Interchange (EDI) were, however, left behind, leaving a large gap in firm's IT infrastructure, which result in low capability of many firms in facilitating electronic transactions.

The most commonly used technologies are Point-ofSales (POS) system and bar-coding, which can be found in almost any supermarket. However, given the limited EDI and data analysis capabilities, the POS system is mainly used for checkout purposes only. The data collected through the system are rarely utilized for sale analysis or inventory management purposes [32]. With plenty of low cost labor working in the supermarket stores, it is apparent that computerized systems are not typically required for labor saving purposes. Sinclair et al. (1998) argue that many supermarkets in China installed computerized applications systems with an assumption that these applications' full potential benefits will eventually be realized.

Major supermarket players have taken the first step towards adopting e-Commerce technologies. In order to effectively coordinate a large number of suppliers, Business-to-Business (B2B) portals were established as a means to communicate with the suppliers electronically without worrying about the system compatibility as well as hardware and software investment at the suppliers' end. By logging into the retailers' B2B portals through the Internet, suppliers are able to obtain information about their products and hence make replenishment decisions accordingly. This approach has allowed the supermarkets to bypass the inadequate information technology infrastructure and realize some degree of VMI without significant investments.

Warehouse Management System (WMS) is another application that has been adopted by major chains to improve their operational efficiency. It is usually a standalone system that tracks and coordinates the inventory movement within the distribution centre by assisting warehouse staff to accurately store incoming inventory and prepare outgoing orders. All incoming stock is first entered into the WMS manually upon arrival to update the inventory record and generate a storage slip. It is then placed onto the inventory transportation terminal which automatically stores the inventory into the appropriate place in the warehouse. Upon receiving store orders, WMS generates an outgoing inventory slip to list stocks required and their locations in the warehouse to assist the manual pick-andpack process. Although this system seems to be primitive based on the western standard, it is one major step forward for the Chinese supermarket chains to achieve automatic inventory control.

To further investigate e-Commerce readiness within the Grocery industry, empirical data were collected through interviews with various industry players. The study was guided by technology-organizationenvironment framework developed by Tornatzky and Fleischer (1990) as briefly discussed below.

\section{Theoretical Framework}

Technology-organization-environment framework was developed by Tornatzky and Fleischer to study the adoption of technology innovation in general. It examines three aspects of technology adoption, namely technological, organizational and environmental contexts, to determine the likelihood of adoption success for certain technology innovations [33]. The technological context mainly deals with the existing technologies within the organizations and technologies 
available in the market. In this study, it represents the IT capability of the firm, which is positively linked with eCommerce adoption. The organizational context usually comprises factors such as firm size, scope, hierarchical structure, managerial philosophy, quality of human resources and the availability of excess resources within the organization. The environment context represents the environment in which the organization operates. It concerns with government and the industry including the competitors and suppliers [27, 33]. This framework was chosen for this study because it has been widely used in various technology adoption studies[27, 33]. Although the factors examined in each context vary between studies, its solid theoretical basis and consistent support from empirical studies warrants its use in the studying of e-Commerce readiness in this case $[14,16]$.

Figure 1 summarizes various factors which are relevant in this study within each context. Given the permeable nature of business boundaries, different contexts can directly and indirectly impact e-Commerce readiness through influencing other contexts, as indicated by the two-way arrows in Figure 1. The interview questions were structured to reflect the interactive nature of these contexts by drawing references between different sections throughout the interview to explore the interrelationships between the different contexts. More detailed discussion on the interview questions are discussed in the next section.

\section{Figure 1: E-Commerce readiness conceptual model}

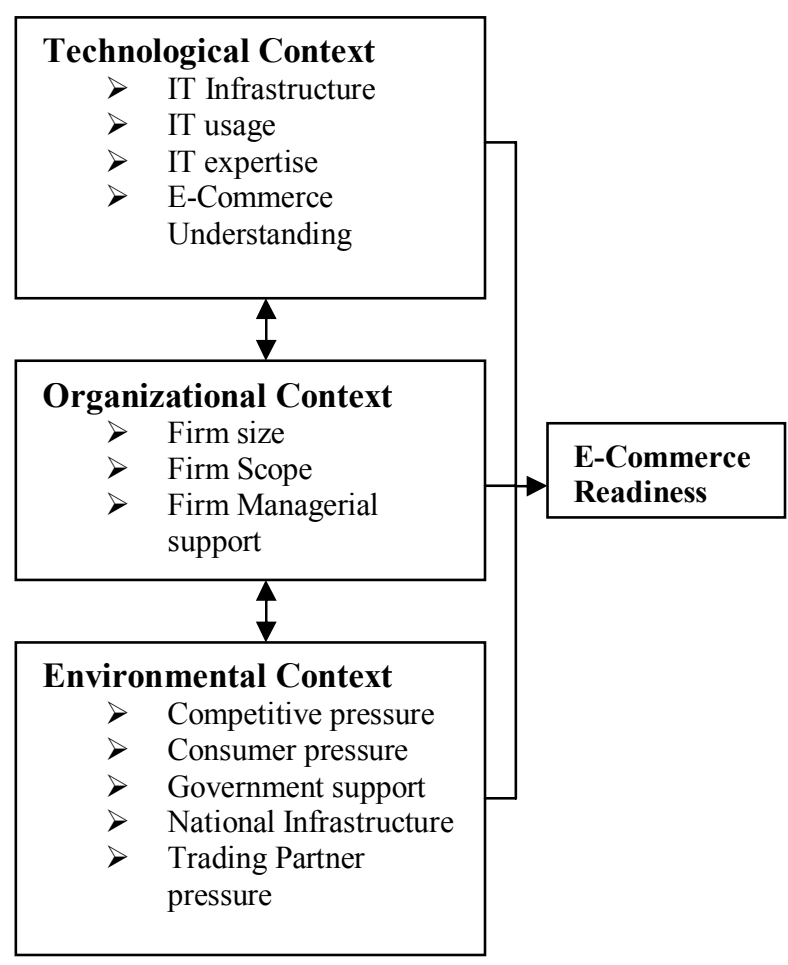

\section{Research Method}

This study employs a multiple case study with various organizations within the Chinese grocery industry. By involving manufacturers, distributors and retailers of the grocery industry instead of the retailers only as in most of e-Commerce surveys and studies conducted in China, a better and unbiased picture of eCommerce adoption can be obtained

The unit of analysis is individual organization. Semistructured interviews were used as the data collection technique. The interview questions were guided by the theoretical framework shown in Figure 1. The participating firms' technological context was examined by exploring its current IT usage, infrastructure, expertise and e-Commerce understanding both within the firm and its environment. Organizational context is addressed through exploring the target firms' size, scope and managerial support for e-Commerce. By enquiring the interviewees about the adoption pressure from the competitors, trading partners and the government, as well as the national infrastructure, the environmental context was also explored in the interviews

At the time of writing, interviews have been conducted with six organizations of various sizes and types, with different IT experiences and adoption levels. Future interviews will be conducted during the next twelve months to complement the current study findings. Completed interviews were conducted with the senior managers of the organization with an estimated duration of thirty minutes to one hour, depending on the organization's experience with information technologies and e-Commerce. The semi-structured nature of the interview allowed the interviewer to actively adapt the interview questions according to the interviewee's specific situation and responses while maintaining a firm grip on the topics covered. By formulating interview questions into open-ended queries, interviewees usually reveal more in-depth information for each context. Responses that were unexpected or interesting were followed up immediately to gain better understanding of the issues raised.

At the end of each interview, the information obtained was checked against the prepared questions to ensure that all questions had been answered. Interview data were tape-recorded and later transcribed as a written-up field note. Qualitative data analysis technique was used in data analysis to identify and categorize themes/concepts of interest through close examination of data in the written-up field notes. Cross case analyses were also conducted to compare the findings from different interviews. Through the cross case comparison, various emerging concepts were then refined.

\section{The Participants}

Table 3 summarizes the profile of the participating organizations in this study. Company $\mathrm{A}$ is a major 
manufacturer of instant noodles in China, with supermarkets as its major retail outlets. Employing around three hundred and fifty full-time employees, it is a typical well-established traditional grocery manufacturer in China. Despite its mixed ownership, Company A's operation largely remains unchanged with limited addition of stand-alone computers and the Internet used by the management level. With virtually no dedicated IT investment, businesses are carried out through the conventional medium: face-to-face interaction and telephone conversations. The interviewee (Regional Manager) demonstrated little understanding of e-Commerce and was not enthusiastic about the prospects of future adoption within the organization, since the traditional way had been working well.

Table 3: Participants' Profile

\begin{tabular}{|c|c|c|l|}
\hline Company & Type & $\begin{array}{l}\text { Full-time } \\
\text { employee }\end{array}$ & Ownership \\
\hline A & Manufacturer & 350 & $\begin{array}{l}\text { Local with } \\
\text { foreign } \\
\text { ownership }\end{array}$ \\
\hline B & Broker & 25 & Local \\
\hline C & Retailer & 80 & $\begin{array}{l}\text { Local with } \\
\text { foreign } \\
\text { ownership }\end{array}$ \\
\hline D & Retailer & $500+$ & Local \\
\hline E & Retailer & 65 & Local \\
\hline F & Distributor & 15 & $\begin{array}{l}\text { Multi- } \\
\text { national } \\
\text { Chain }\end{array}$ \\
\hline & & & \multicolumn{2}{|l}{} \\
\hline
\end{tabular}

Company B is a small broker of grocery items with twenty-five full-time employees. As most of other similar sized grocery distributors in China, it is independent and locally-owned. Given its recent establishment, its operation is unsurprisingly supported by IT, which gives all employees direct access to computers, Internet and E-mail. Since most of company B's employees have a tertiary degree, the interviewee (Chief Executive Officer) showed a comprehensive understanding of e-Commerce and indicated willingness in its future investment because of the organization's positive experience with IT.

Company $\mathrm{C}$ is a medium sized grocery retailer with foreign ownership. As other grocery retailers in China, it is equipped with the standard information technologies such as Scanner/Bar-coding, Internet and Website to attract customers and facilitate its day-to-day operation. The majority of the staff at the management level holds a tertiary degres. The interviewee (Marketing Manager) also demonstrated adequate e-Commerce knowledge and expressed commitment in maintaining the current level of IT investment, but with limited willingness to further increase e-Commerce adoption in the near future.
Company D is one of the major retailers in China. It was a SOE until the recent privatization. As the largest player in the region, it is very well funded and has a team of highly educated managers. Compare to the other locally owned retailers, Company D is relatively more advanced in the e-Commerce adoption. It does not only possess the basic technologies such as Scanner/Barcoding and the Internet, but it also has taken one step forward in adopting B2B and B2C e-Commerce setting up a sophisticated transactional and interactive website which offers online shopping, after sale service for the customers and acts as a communication portal for their business partners.

Company $\mathrm{E}$ is a small, local grocery retailer with around sixty fulltime employees. Because of its small size, it lacks the financial and technical resources to adopt any advanced technologies. It is equipped with the industry standard Scanner/Bar-coding system, E-mail, Internet and has an interactive website that accepts online payment. The interviewee (General Manager) completed a tertiary education and demonstrated sound understanding of e-Commerce and its potential.

Company $\mathrm{F}$ is a part of a multinational grocery distribution chain. Its local office has only fifteen fulltime employees, but due to its foreign heritage, it invests heavily in information technologies and uses them extensively in its day-to-day operations. Although their financial resources are still limited, all of the employees have direct access to personal computers, the Internet and E-mail. During the interview, the general manager also demonstrated good e-Commerce knowledge.

\section{Study Findings}

Interviews with the participants reveal some important observations related to e-Commerce readiness within the grocery industry in China. Discussion of the findings is based on the three contexts of the underlying theoretical model.

\subsection{Technological Context}

\section{Sound IT and telecommunication infrastructure}

All organizations interviewed have established some basic IT infrastructures except company A. It appears that retailers have the most developed IT backbone infrastructure due to its extensive use of POS systems and exposure to the international competition. Company $\mathrm{D}$, as one of the major retailers, has implemented interactive and transactional website for conducting B2C transactions and attracting business partners. Other interviewed retailers and distributors all possess sound IT infrastructures, mainly consisting of a network of computers with direct access to the Internet and various other hardware and software. On the other hand, all participants responded very positively when enquired 
about the IT infrastructure in their immediate market. The national telecommunication infrastructure, in particular, was believed to be reliable and effective.

\section{IT is mainly used to support low level administration activities}

Despite the active use of information technologies in daily businesses by all adopting companies, only company D has demonstrated sophisticated e-Commerce capabilities beyond the basic E-mail communication and administration tasks. The Internet and e-mail are the most commonly used information technologies within the participating organizations, enabling them to place and receive orders electronicallly. Other applications such as EFT and Barcode/Scanner are purely used for basic operational purposes only. Once again, company D is the only interviewed company that possesses compatible or inter-connected systems with its trading partners. Table 4 depicts the current use of technologies by the participating companies.

\begin{tabular}{|c|c|c|c|}
\hline Company & $\begin{array}{l}\text { e-Commerce } \\
\text { technologies }\end{array}$ & $\begin{array}{c}\text { Sales } \\
(\%)\end{array}$ & $\begin{array}{c}\text { Business } \\
\text { operation } \\
(\%)\end{array}$ \\
\hline $\mathrm{A}$ & Internet, e-mail & 0 & 0 \\
\hline B & $\begin{array}{l}\text { Internet, e-mail, } \\
\text { EFT, Intranet }\end{array}$ & $5 \%$ & $6 \%$ \\
\hline $\mathrm{C}$ & $\begin{array}{l}\text { Internet, e-mail, } \\
\text { EFT, } \\
\text { Barcode/Scanner }\end{array}$ & $6-7 \%$ & $10 \%$ \\
\hline $\mathrm{D}$ & $\begin{array}{l}\text { Internet, Intranet, } \\
\text { e-mail, EFT, } \\
\text { Barcode/Scanner }\end{array}$ & $5 \%$ & $40 \%$ \\
\hline$E$ & $\begin{array}{l}\text { Internet, Intranet, } \\
\text { e-mail, EFT, } \\
\text { Barcode/Scanner }\end{array}$ & $5 \%$ & $100 \%$ \\
\hline $\mathrm{F}$ & $\begin{array}{l}\text { Internet, e-mail, } \\
\text { Intranet, EFT }\end{array}$ & $4 \%$ & $75 \%$ \\
\hline
\end{tabular}

Table 4: IT Use by the Participating Organizations

Sound understanding of e-Commerce but internal IT expertise is largely limited

During the interviews, all respondents except Company A demonstrated a good understanding of e-Commerce and its potential benefits, threats and opportunities. However, when asked about the existence of IT expertise within the firm to support future advancement of eCommerce, only Companies $\mathrm{C}$ and $\mathrm{F}$ provided an affirmative answer. Other respondents were unsure about the adequacy of their current internal IT expertise. However, companies with strong financial resources such as Companies C and D further explain their intention to recruit more technical personnel to rectify this problem in the near future. Despite the various responses regarding the availability of internal IT expertise, all respondents believe that there is plenty of
IT expertise in the market given the yearly increase of IT graduates.

\subsection{Organizational Context}

\section{Firm's scope positively links with e-Commerce readiness}

From the analysis of the interviews, a positive relationship has been identified between firm's scope and firm's enthusiasm in e-Commerce adoption. Retailers (Companies C, D and E), as the dominant players within the industry based on both size and scope of the product offerings, have a positive attitude towards e-Commerce adoption. They have the required resources for e-Commerce adoption and are the most optimistic about e-Commerce potential in enhancing their performance. The distributors (Companies B and F), although smaller in size compared to the manufacturers, their business scope is much broader. Since distributors are expected to offer a wide range of services, the benefits of e-Commerce obtained from coordination of activities is especially attractive to them. As a result, they are also relatively willing to commit future investment to the adoption of e-Commerce. However, due to their small size and limited financial resources, their may face some challenges in e-Commerce adoption. Finally, the manufacturer (Company A), although large in size, lacks the scope to make e-Commerce appealing to them. This was reflected by their unwillingness to undertake advancement in e-Commerce.

\section{Support from senior managers}

In general, the interviews showed surprisingly strong supports from the top management level for IT implementations and upgrades. This can be attributed to China's hierarchical decision making structure where all important business decisions are originated from the top level, which is expressed below:

"...of course we gave our full support for computerizing the workplace and putting up a website. We are the ones that proposed the idea and made the final call after all." (Company C)

With the adoption decisions originated from the top level management, the implementation processes are usually supported with abundant financial and human resources. The collective nature of the Chinese culture also contributes significantly to the smooth introduction of new technologies, as revealed below:

"... once a decision was made, we all see it as our own goal to see the decision being carried through. We work as a single entity and resistance to the change is minimal. After all, we (senior managers) all agreed upon the necessity for introducing e-Commerce into our business." (Company D) 


\subsection{Environmental Context}

\section{Telecommunication and transport infrastructure disparity}

Since all of the participating organizations are located in the economically advanced east coast region of China, all interviewees gave high ratings regarding the transportation infrastructures in the region. None of the adopting company suffered infrastructure related difficulties during or after the IT adoption. Furthermore, Company D's e-Commerce operations are believed to be well supported by the existing infrastructures. Company $\mathrm{D}$ was also very confident that these infrastructures are mature enough to support the existing and future eCommerce activities in the region. However, the Marketing Manager of Company $\mathrm{C}$ expressed her doubt regarding the condition of these basic infrastructures in less developed regions of China. It confirms the findings of other similar studies (see for example [5, 19, 22, 24, 28] ) that there is a significant infrastructure development disparity in China between the economically developed regions and the rural areas.

\section{Weak legal framework and privacy protection}

When asked about the state legal framework for online transactions, all interviewees expressed their discontentment. All of them believed there is a significant lack of sound laws and regulations that can effectively monitor e-Commerce activities and, hence, China is considered not to be ready for e-Commerce in this respect. With the "lack of e-Commerce legal framework" identified as major barriers to e-Commerce adoption in previous studies [5, 19, 22, 24, 28], this finding further confirms the presence of the barrier related to legal framework in China, which affects the adoption of e-Commerce within the grocery industry in particular and other industries in general.

\section{Organization's position in the supply chain affects e- Commerce adoption}

The interviews suggest that the closer the organization is to the consumer, the more information technologies are used as part of daily business procedures. With all interviewees confirming their IT and basic e-Commerce adoption situation as the industry standard practice, we can conclude that this phenomenon is relatively wide-spread within the grocery industry. Company A, the manufacturer, located further away from the consumer than other companies, repeatedly questioned the necessity of e-Commerce technologies in the manufacturing sector and expressed contentment regarding their traditional way of operation under the current situation as revealed below:

"...at the moment, our business is operating with the traditional approach and performing well, we are not really looking into any e-Commerce initiatives" (Company A).

Other participating companies, on the other hand, demonstrated a much more advanced e-Commerce understanding and IT usage. Being able to meet consumer demand is considered by the majority of the participants to be one of the major reasons for adopting IT and introducing e-Commerce. Meanwhile, Companies $\mathrm{C}, \mathrm{D}$ and $\mathrm{E}$ (retailers), use information technology to a much greater extent than Companies $\mathrm{B}$ and $\mathrm{F}$ (distributors). This finding is consistent with the other eCommerce survey carried out in Chin, that identify "consumer demand" as the number one driver for eCommerce adoption [28].

\section{Lack of trust among trading partners}

After a decade of e-Commerce development and diffusion in China, it appears that some organizations finally started to develop a sense of trust in their business relationships. All respondents except Company D, confirmed the existence of a trustful relationship with their trading partners. However, the level of trust is still considered low. When asked about the sharing of information with their partners, all IT capable organizations ( $\mathrm{B}, \mathrm{C}, \mathrm{E}$ and $\mathrm{F})$ indicated reluctance in sharing important information. It appears that although businesses have made improvements in the trust level among trading partners, they are still largely cautious in cooperating with their partners, as revealed by the interview excerpt:

"We trust our trading partners as much as they can be trusted" (Company C).

On the other hand, Company D, as the largest retailer in its region, strongly denied the existence of such relationship. The interviewee believes that the suppliers will not hesitate to take advantage of the situation if they are not monitored carefully and he personally has unpleasant experiences in dealing with them. Conflicts between large retailers and their suppliers are widespread in China, which sometime can escalate to violent confrontations between the two parties [7, 18]. Such volatile retailer-supplier relationship is the result of power imbalance and the lack of business regulations and enforcement in China $[11-13,15,19,20]$. This observation confirms the widely quoted "lack-of-trust" syndrome which is believed to be prevalent within the Chinese business environment [3, 4, 6, 8, 22-24]. Lack of trust is believed to be one of the major impediments to B2B e-Commerce adoption.

\section{Discussion and Conclusions}

Based on the characteristics of the Chinese grocery industry and its consumers as explored in this study, it appears that e-Commerce is relevant and it has many potential benefits to offer to the industry. As further indicated in the study, IT has been widely used within 
the industry to various degrees, with the retailer leading the way in incorporating IT into the majority of their daily operations. Such IT adoption provides basic eCommerce infrastructure within the organizations. Some of the major retailers have already progressed further into e-Commerce adoption by introducing transactional and interactive websites to facilitate B2C and B2B eCommerce, but many organizations within the industry possess only standalone internal computer networks and informational websites. The abundance of IT expertise in the market and the good understanding of eCommerce demonstrated by the majority of participants are very positive indicators of the e-Commerce readiness of the industry. However, unless rectified, the barriers of poor national legal framework and e-Commerce infrastructure will confine future e-Commerce adoption, involving only fragmented networks and standalone applications.

In addition, the power issue and the lack of trust between retailers and suppliers can significantly hinder the development of e-Commerce. Despite retailers' enormous effort to impose standards and operations upon their suppliers, the amount of investments required for eCommerce adoption is simply too large for the majority of distributors and manufacturers to bear. Unlike in other countries such Australia, since the industry is only dominated by two large retailers, it is relatively easier for the Australian retailers to mandate their requirements to manufacturers and other trading partners than the retailers in China [19]. The lack of trust between the two parties also significantly hinders further e-Commerce adoption. As a result, the retailers simply choose to impose numerous expenses upon the suppliers to increase their profit margin instead $[11,20]$. This will further create barriers to e-Commerce adoption since the mutuality of costs, benefits and risks among various parties is important for adoption [19].

Based on this study, e-Commerce readiness of the Chinese grocery industry is still considered rather low since the e-Commerce readiness varies significantly between different sectors. Retailers as the most technologically sophisticated and most resourceful players are generally ready for adopting basic eCommerce initiatives. However, its business environment and operational philosophy need to be updated before progressing any further, since eCommerce adoption typically requires a concerted effort among various parties within the supply chain [19]. The distributors lack the resources and business scale to make e-Commerce viable at the moment, and the manufacturers are not ready for e-Commerce based on the observations from this study. In order to help the grocery industry improve its e-Commerce readiness and consequently increase its chance to capitalize on the eCommerce technologies in the future, some suggestions are proposed below, based on the findings of this study.
In terms of the technological context, the grocery industry as a whole lacks e-Commerce facilitating technologies such as EDI and e-Commerce operation standard. For e-Commerce to be introduced successfully within the industry, it is crucial not only to have a firm hardware backbone but also universal operation and communication standards and protocols. The national and industry governing bodies need to provide incentives and assistance to promote investments in the adoption of such technologies. Only by establishing a solid operation foundation, firms are able to reap the full benefit of eCommerce in the future. Based on the experience in western countries, this process may take several years as it is not easy to coordinate and streamline business processes to implement e-Commerce initiatives. However, with the advancement in the Internet based eCommerce applications, it is hoped that China and other developing countries can bypass some early problems related to high costs and compatibility, faced by organizations in western countries, in implementing eCommerce such as EDI.

The study findings also suggest that the awareness and understanding of e-Commerce potential need to be improved in the manufacturing sector to further encourage adoption. This may require the involvement of the industry body that can improve the visibility of eCommerce practices among the industry players and to demonstrate the benefits obtained. Through progressively increasing the awareness and understanding of e-Commerce business practices and procedures, more and more organizations will be willing to consider e-Commerce as means of organizational improvement.

To facilitate the future adoption of e-Commerce, the environmental context of the industry also needs restructuring. Laws and regulations need to be put into place to protect vulnerable parties and rebuild the sense of trust between trading partners. Stronger legal frameworks will also help facilitate online activities and reassure organizations when conducting e-Commerce.

Although the current study is limited by the small number of participants interviewed and organizations involved within the industry, a general picture of the eCommerce readiness in the China's grocery industry has been obtained. Based on the analysis of the characteristics of the Chinese grocery industry, the potential of e-Commerce and the conditions of the organizations within the industry, some useful suggestions have been offered to further encourage eCommerce adoption within the Chinese grocery industry. The study findings will thus provide points of reference for the governing bodies and the industry players of the China's grocery industry to promote effective eCommerce adoption. Other developing countries, especially those which share some common characteristics can also learn from the Chinese grocery 
industry case reported in this study to understand the eCommerce potential, assess their own e-Commerce readiness and formulate appropriate strategies for eCommerce adoption.

\section{References}

1. Ackerman, D. and G. Tellis, Can culture affect prices? A cross-cultural study of shopping and retail prices. Journal of Retailing, 2001. 77: p. 57-82.

2. Associates, K.S., Efficient Consumer Response: Enhancing Consumer Value in the Grocery Industry. 1993, Food Marketing Institute: Washington D.C.

3. Bean, R., China, Peoples Republic of Retail Food sector All China retail Annual Report, in USDA Foreign Agricultural Service GAIN Report, R. Kreamer, Editor. 2006. p. 1-34.

4. Chae, B., H.R. Yen, and C. Sheu, Information Technology and Supply Chain Collaboration: Moderating Effects of Existing Relationships between Partners. IEEE transactions on engineering management, 2005. 52(4): p. 440-449.

5. Chvaja, A., I. Mokudai, and N. Efendic, Ecommerce in China Challenge of the 21st Century. 2001, University of Hong Kong: Hong Kong.

6. Dedrick, J. and K.L. Kraemer, China IT Report. The Electronic Journal on Information Systems in Developing Countries, 2001. 6(2): p. 1-10.

7. Dickson, M.A. and L. Zhang, Supplier-retailer relationships in China's distribution channel for foreign brand apparel. Journal of Fashion Marketing and Management, 2004. 8(2): p. 201-220.

8. Efendioglu, A.M. and V. F.Yip, Chinese culture and ecommerce: an exploratory study. Interacting with Computers, 2004. 16: p. 45-62.

9. Goldman, A., Supermarkets in China: Entry limitations and strategic dilemmas, in MKTG 96.080. 1996, China Europe International Business School. p. 1-34.

10. Goldman, A., Supermarkets in China: the case of Shanghai. International Review of Retail, Distribution and Consumer Research, January 2001. 10(1): p. 1-21.

11. Guan, S. and L. Wang. Analysis of restrictive factors of Ecommerce implemented in Traditional retail trade in China. in ICEC. 2005. Xi'an: ACM.

12. Hansen, K., Purchasing decision behavior by Chinese supermarkets. International Review of Retail, Distribution and Consumer Research, April 2001. 11(2): p. 159-175.

13. Hu, D., et al., The Emergence of Supermarkets with Chinese Characteristics: Challenges and Opportunities for China's Agricultural Development. Development Policy Review, 2004. 22(5): p. 557-586.

14. Iacovou, C.L., I. Benbasat, and A.S. Dexter, Electronic data interchange and small organizations: Adoption and Impact of Technology. MIS Quarterly, 1995. 19(4): p. 465485.

15. Jiang, B. and E. Prater, Distribution and Logistics development in China: the revolution has begun. International Journal of Physical Distribution \& Logistics Management, 2002. 32(9): p. 783-798.

16. Kuan, K.K.Y. and P.Y.K. Chau, A Perception-based model for EDI adoption in small business using a TechnologyOrganization-Environment Framework. Information and Management, 2001. 35: p. 507-512.
17. Kurnia, S. and R.B. Johnston, Adoption of Efficient Consumer Response: The Issue of Mutuality. Supply Chain Management: An International Journal, 2001. 6(5): p. 230241.

18. Liu, H. and Y.P. Wang, Coordination of international channel relationships: four case studies in the food industry in China. Journal of Business \& Industrial Marketing, 1999. 14(2): p. 130-151.

19. Lo, T.W.-C., H.-F. Lau, and G.-S. Lin, Problems and prospects of supermarket development in China. International Journal of Retail and Distribution Management, 2001. 29(2): p. 66-76.

20. Luk, S.T.K., Structural changes in China's distribution system. International Journal of Physical Distribution \& Logistics Management, 1997. 28(1): p. 44-67.

21. Mai, L.-W. and H. Zhao, The characteristics of supermarket shoppers in Beijing. International Journal of Retail and Distribution Management, 2004. 32(1): p. 56-62.

22. Martinsons, M.G., and Electronic commerce in China: emerging success stories. Information \& Management, 2001. 39: p. 571-579.

23. Meng, B. Infrastructure, Service and Trust: Assessing the Environment of E-commerce in China. in PTC's 26th annual conference. 2004. Honolulu: Pennsylvania State University.

24. Millington, A., M. Eberhardt, and B. Wilkinson, Gift giving, Guanxi and Illicit payments in Buyer-Supplier relations in China: Analyzing the Experience of UK Companies. Journal of Business Ethics, 2005. 57: p. 255268.

25. Mousteraski, P., People's Republic of China: Retail Food Sector Report 2001, in Global Agricultural Information Network Report. 2001, USDA Foreign Agricultural Service: Washington DC.

26. Odera-Straub, M., E-commerce and Development: Whose Development? The Electronic Journal on Information Systems in Developing Countries, 2003. 11(2): p. 1-5.

27. Oxley, J.E. and B. Yeung, E-Commerce Readiness: Institutional Environment and International Competitiveness. Journal of International Business Studies, 2001. 32(4): p. 705-723.

28. PricewaterhouseCoopers, 2004/2005 Global retail \& consumer study from Beijing to Budapest. 2005. p. 19-31.

29. Qureshi, S. How does information technology affect development? Integrating theory and practice into a process model. in Eleventh American Conference on Information Systems. 2005. Omaha, Ne, USA.

30. Qureshi, S. and A. Davis. Overcoming the Digital Divide through Electronic Commerce: Harnessing opportunities in IT for Development. in 40th Hawaii International Conference on System Sciences. 2007. Hawaii.

31. Simchi-Levi, e.a., Designing and Managing the Supply Chain: Concepts, Strategies and Case Studies. 2003: McGraw-Hill.

32. Sinclair, G., A. Lyer, and J. Anderson, The supermarket supply chain in Shanghai. International Food and Agribusiness Management Review, 1998. 1(4): p. 443-450.

33. Tornatzky, L.G. and M. Fleischer, The Process of Technology Innovation. 1990, Lexington: Lexington Books.

34. UNCTAD, Information Economy Report 2005, in United Nations Conference on Trade and Development. 2005: New York and Geneva. 
